\title{
PARATHYROID STATUS AND ITS ASSOCIATION WITH HAEMOGLOBINOPATHIES AMONG TYPE2 DIABETES MELLITUS IN SOUTHERN NIGERIA
}

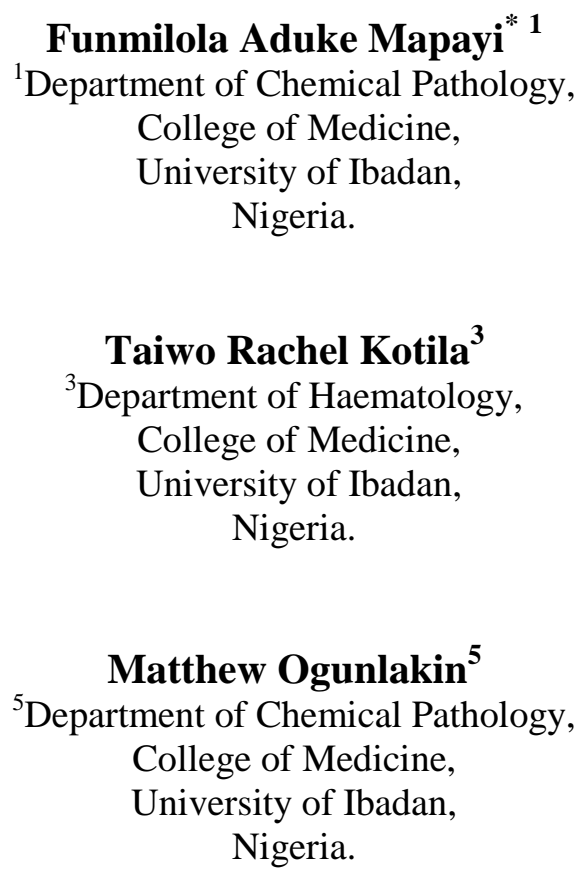

\author{
Mabel Ayebatonyo Charles-Davies ${ }^{2}$ \\ ${ }^{2}$ Department of Chemical Pathology, \\ College of Medicine, \\ University of Ibadan,
}

Nigeria.
Jokotade Oluremilekun Adeleye $\mathbf{4}^{4}$
${ }^{4}$ Department of Medicine,
College of Medicine,
University of Ibadan,
Nigeria.

\author{
Felix Rotimi Afolabi ${ }^{6}$ \\ ${ }^{6}$ Department of Epidemiology and Medical \\ Statistics, \\ College of Medicine, \\ University of Ibadan, \\ Nigeria.
}

*For correspondence: Funmilola Aduke Mapayi

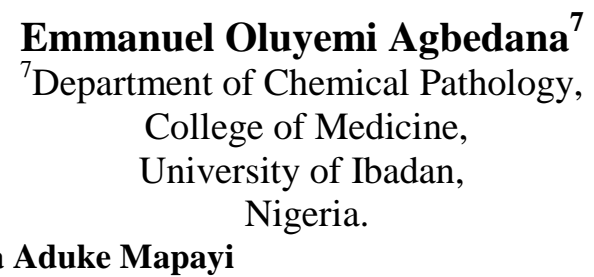

Article DOI: https://doi.org/10.36713/epra6232

\footnotetext{
ABSTRACT

Background: Endocrine action is integrative and an endocrine dysfunction of one gland is known to affect other endocrine glands. Parathyroid glands are associated with the beta cell function. Thus, insulin resistance observed in type 2 diabetes mellitus (T2DM) may be associated with alterations of parathyroid hormones and their metabolic pathways. These have been reported to have a genetic root, postulated to be aberrant haemoglobin gene resulting in haemoglobin variants. This has not been fully explored in sub-Saharan Africa, which has significant population of haemoglobin variants.

Aim: The aim of this study was to evaluate the status of parathyroid dysfunction and its association with haemoglobinopathies among Sub-Saharan Africans with type 2 diabetes mellitus.

Method: A total of 204 individuals aged 25 - 80 years which comprised 100 T2DM and 104 Controls without T2DM were enrolled from a tertiary hospital, in Ibadan, Nigeria and environs.10mL intravenous blood was obtained from each participant. Parathyroid Hormone (PTH) was measured using enzyme linked immunosorbent assay (ELISA). Calcium, Phosphate, Albumin and Fasting Plasma Glucose (FPG) were analysed spectrophotometrically. Haemoglobin A2 (HbA2), Haemoglobin A (HbA), Haemoglobin C (HbC) and Haemoglobin $S$ (HbS) and Glycated haemoglobin (HbAlc) were determined by High Performance Liquid Chromatography (HPLC) method using Variant Haemoglobin Testing System (Bio-Rad Variant II). Data analysed using appropriate statistical analysis were significant at $p<0.05$.
} 
Results: Normal parathyroid function, hyperparathyroidism and hypoparathyroidism were present in 93\% vs $96 \%, 3 \%$ vs $0.96 \%$ and $4 \%$ vs $6.73 \%$ in T2DM and controls respectively. T2DM and controls with AA and Non AA had $62 \%$ vs $31 \%$ normoparathyroidism, $3 \%$ vs $0 \%$ hyperparathyroidism and $2 \%$ vs $2 \%$ hypoparathyroidism respectively. The association between parathyroid gland disorder in T2DM and controls with the various haemoglobin variants was not significant (p>0.05) but the difference between parathyroid function in the control group with and without Beta Thalassaemia Trait was significant $(p<0.05)$.

Conclusion: Hypoparathyroidism and hyperparathyroidism were revealed in Type 2 Diabetes Mellitus and control individuals with haemoglobin genotype $A A(H b A A)$. Hypoparathyroidism was also found among controls with Beta Thalassaemia Trait. Timely identification of these disorders may be helpful in appropriate therapeutic regimen to facilitate bone growth, prevent fractures and complications of parathyroid gland in these individuals.

KEYWORDS: Haemoglobin Variants, Parathyroid Dysfunction, Type 2 Diabetes Mellitus (T2DM).

\subsection{INTRODUCTION}

Recent epidemiological studies have shown increasing prevalence of Type 2 diabetes mellitus (T2DM) in developed and developing countries (Dianna et al., 2019). T2DM is principally linked with insulin secretory defects, which may be related to inflammation, metabolic stress and genetic factors, manifesting clinically as hyperglycemia (Diabetes Care, 2019). Diabetes and osteoporosis are prevalent chronic diseases with serious clinical complications (Cipriani et al., 2020). Reduced metabolic control of diabetes mellitus may possibly prompt defects in calcium homeostasis and affect bone mineral metabolism (Cipriani et al., 2020).

Calcium $(\mathrm{Ca})$ is an essential mineral that exerts a wide range of biological functions, including bone and tooth mineralisation, blood coagulation, muscle contraction, nerve impulse transmission and cellular signalling transduction (Sorva et al., 1990; Peacock, 2010; Becerra-Tomás et al., 2014; Rooney et al., 2016 \& Sing et al., 2016). Ca also plays a fundamental role in insulin secretion and glucose homeostasis (Mears, 2004; Becerra-Tomás et al., 2014 and Zaccardi et al., 2015). Glucose-dependent insulin secretion is a $\mathrm{Ca}$ regulated process, which is dependent on intracellular $\mathrm{Ca}$ concentration in pancreatic $\beta$ - cells (Wollheim et al., 1981 \& Zaccardi et al., 2015). Additionally, increased cytosolic Ca also affects glucose uptake in the myocyte (Begum et al., 1993; Ojuka et al., 2002 \& Zaccardi et al., 2015).

$\mathrm{Ca}$ homeostasis abnormality could therefore, be potentially involved in insulin action defects and disorders in glucose homeostasis, causing T2DM advancement (Procopio et al., 2002; Mears, 2004; Becerra-Tomás et al., 2014; Zaccardi et al., 2015). An increase in parathyroid hormone (PTH) secretion may occur to correct the chance of reduction in calcium (Seino et al., 1995).

Parathyroid Hormone (PTH) is a polypeptide that comprises 84 amino acids (Chang et al., 2009), which preserves the extracellular calcium levels within a narrow normal range and controls plasma calcium homoeostasis (Stanley et al., 2013). The parathyroid glands secrete PTH in response to low calcium levels causing an increase in bone resorption and maintaining extracellular calcium through direct effect on the kidneys and bones as well as an indirect impact on the small intestine.

The association of parathyroid hormone (PTH) with insulin resistance has been demonstrated (Chang et al., 2009). The development of diabetes has been linked with elevated PTH concentrations with insulin resistance, beta cell dysfunction, and abnormal glucose levels (Chiu et al., 2000; Reis et al., 2007; Reis et al., 2008; Kramer et al., 2014). High levels of PTH is predominant in diabetes mellitus by two to four times the levels in individuals without T2DM (Rahimi, 2014). Studies of patients with primary hyperparathyroidism have shown a higher prevalence of diabetes compared to control populations (Werner et al., 1974; Ljunghall et al., 1983; Cheung et al., 1986 \& Taylor, 1991).

Hyperparathyroidism is a disease characterized by autonomous excess production of PTH resulting in hypercalcemia. Overproduction of PTH results in mobilization of calcium from bone and inhibition of the renal reabsorption of phosphate, resulting to hypercalcemia and hypophosphatemia (Dariusz et al., 2012). PTH downregulates the insulin receptors peripherally, increases insulin resistance and has a direct effect on beta cells (Murray, 2005). Both primary and secondary hyperparathyroidism are involved in abnormal glucose metabolism. Ivarsson et al. (2014) reported a higher prevalence of diabetes mellitus in patients with primary hyperparathyroidism while the removal of parathyroid glands improve glucose tolerance in these individuals (Hamed et al., 2011).

Hypoparathyroidism is thought to be a rare complication, that is usually, but not always complemented by hypocalcemia (Chern et al., 2003). A relationship exsists between reduced levels of PTH and vertebral fracture in T2DM patients (Yamamoto et al., 2012), which could be associated with the diminished anabolic effects of PTH on bones (Wang et al., 2005). Hypoparathyroidism is defined by decreased serum calcium and increased phosphorous levels, complemented by the reduced PTH (Ali Bazi et al., 2018). Parathyroid hormone (PTH) concentrations is likely to be $20 \%-50 \%$ lower in T2DM subjects in than in controls (Dobnig et al., 2006 \& Yamamoto et al., 2012). Reduced parathyroid hormone (PTH) in the blood results in 
decreased calcium and calcitonin. Deficient parathyroid hormone leads to hypocalcemia symptoms including pain and muscle cramp, numbness, tingling, seizures, carpopedal spasms, Trousseau and Chvostek signs (Yavari , 2014; Ferrara et al., 2002; Al-Akhras et al., 2016).

Genetic factors appear to be important in the development of reduced bone mass and osteoporotic fractures (Voskaridou et al., 2013), which are often prominent in T2DM (Hothersall et al. 2014; Sellmeyer et al., 2016). T2DM and parathyroid dysfunction are associated endocrinopathies with genetic basis, largely attributed to haemoglobinopathies.

Hemoglobinopathies are the most common genetically inherited single-gene disorders in the world (Goonasekera et al., 2018). Heamoglobin disorders are divided into quantitative and qualitative defects in globin synthesis. Quantitative defects result to thalassemia syndromes, often with normal globin structure. Hemoglobin variants result from qualitative defects with point mutations in globins (Kohne 2011; Payandeh et al. 2014; Brancaleoni et al. 2016). The two major types are structural haemoglobin variants $(\mathrm{HbC}$, Haemoglobin E $(\mathrm{HbE})$ and $\mathrm{HbS}$ ) and thalassemia syndromes ( $\alpha$ - and $\beta$ thalassemia) are known (Kohne, 2011). Several Investigators have identified about 700 structural haemoglobin variants but only three $(\mathrm{Hb} \mathrm{S}, \mathrm{Hb} \mathrm{C}$, and $\mathrm{Hb} \mathrm{E}$ ) are predominant (Lal et al., 2010).

Bone disease has been characterized as an evident cause of morbidity in individuals with thalassaemia and other haemoglobin disorders. The risk of T2DM, gestational diabetes, osteoporosis, renal diseases, decreasing pulmonary functions and dental problems is shown to be increased in a individuals with beta thalassemia minor (Leung \& Lao, 2012; Giusti et al., 2016; Helmi et al., 2017 and Nickavar et al., 2017. (Voskaridou et al., 2013). Hypoparathyroidism with reduced serum calcium levels in thalassemia patients was improved with vitamin D and calcium supplementation (Goyal et al., 2010).

Several studies have reported parathyroid gland status in diabetes mellitus in different populace but reports on the effect of haemoglobin disorders on parathyroid function in T2DM individuals in African blacks, are unavailable. Hence, the aim of this study is to determine the association of haemoglobin variants with parathyroid dysfunction among T2DM in Southern Nigeria.

\subsection{METHODOLOGY \\ 2.1 Study Design}

This is a case control study and was approved by the Joint Ethical Committee of the tertiary hospital in Ibadan, Nigeria.

\section{2uParticipants}

204 (two hundred and four) participants consisting of 100 (one hundred) T2DM and 104 (one hundred and four) without T2DM (controls) volunteers who gave their consent were enrolled from a tertiary hospital, in Ibadan, Nigeria and environs. The diabetic group were confirmed diabetics by a Consultant Endocrinologist using the World Health Organisation Criteria (Venous fasting plasma glucose (FPG) values of $\geq 7.0 \mathrm{mmol} / \mathrm{L}(126 \mathrm{mg} / \mathrm{dL}), 2-\mathrm{h}$ post-load plasma glucose $\geq 11.1 \mathrm{mmol} / \mathrm{L}$ (200 $\mathrm{mg} / \mathrm{dL}$ ) (WHO, 2006), HbA1c $\geq 6.5 \%$ (48 $\mathrm{mmol} / \mathrm{mol}$ ); or a random blood glucose $\geq 11.1$ $\mathrm{mmol} / \mathrm{L}(200 \mathrm{mg} / \mathrm{dL})$ in the presence of signs and symptoms are considered to have diabetes (WHO, 2016). The individuals without T2DM and history of diabetes were volunteer staff of the same tertiary hospital where the cases were recruited and persons without history of diabetes from the environs were selected. All the participants fasted overnight $(10-$ $12 \mathrm{hrs}$ ) and details on biodata, lifestyle, diet and medical history were obtained through a pre- test semi-structured questionnaire.

\subsection{Sample Collection}

Intravenous blood $(8 \mathrm{~mL})$ sample was aseptically obtained by venepuncture from each of the participants after an overnight fast $(10-12$ hours). Four millilitres $(4 \mathrm{~mL})$ of blood was dispensed into labelled vacuum collection tube containing potassium ethylene diamine tetra acid (K3EDTA), stored at $2-8 \mathrm{oC}$ and processed within 7 days of sample collection for the determination of haemoglobin variants ( $\mathrm{HbA} 2, \mathrm{HbA}, \mathrm{HbC}$ and $\mathrm{HbS}$ ) without sample centrifugation. $4 \mathrm{~mL}$ of blood was dispensed into gold-topped serum separator gel tubes for the determination of PTH, Calcium, Albumin, and Phosphorus. Serum/plasma was obtained by centrifuging blood and spun at $500 \mathrm{~g}$ for five minutes. These were stored in small aliquots at $-200 \mathrm{C}$ until analysis was done.

\section{4 Biochemical Investigations}

Biochemical parameters estimated were Fasting Plasma Glucose Serum Parathyroid Hormone (PTH), Calcium, Albumin and Phosphorus and Haemoglobin Variants ( $\mathrm{HbA} 2, \mathrm{HbA}, \mathrm{HbC}$ and $\mathrm{HbS}$ ).

\subsubsection{Fasting Plasma Glucose Estimation}

Fasting Plasma Glucose was determined by glucose oxidase, an enzymatic method (Produktion, Austria), as described by Barham and Trinder, (1972). Participants were classified according to WHO criteria: Normal range for Fasting Plasma Glucose (FPG) was FPG $\leq 110 \mathrm{mg} / \mathrm{dL}(\leq 6.1 \mathrm{mmol} / \mathrm{L})$ (Normal); FPG $(110-125 \mathrm{mg} / \mathrm{dL} \quad(6.1$ to $6.9 \mathrm{mmmol} / \mathrm{L}$ ) (Prediabetes) for the control group and FPG $\geq 126 \mathrm{mg} / \mathrm{dL}$ ( $\geq 7 \mathrm{mmmol} / \mathrm{L}$ ) (Diabetes Mellitus) for the T2DM group (WHO, 2016). 


\subsubsection{Calcium Estimation}

Serum calcium ions was determined by colorimetric method with O-Cresolphthalein complexone without deproteinization medium (Randox Laboratories, Crumlin, United Kingdom) as described by Benedict et al., 1924). The reference range for normal calcium level was 8.10 $10.4 \mathrm{mg} / \mathrm{dL}$.

\subsubsection{Phosphate Estimation}

Serum phosphate ions was determined by the formation of a yellow phosphorus molybdate complex when it reacts with ammonium molybdate and the concentration obtained photometrically (Dialab Produktion, Austria), as described by Thomas (1998). The reference range for normal phosphate was $2.6-4.5 \mathrm{mg} / \mathrm{dL}$.

\subsubsection{Albumin Estimation}

Serum albumin was determined by a colour change of indicator in the presence of bromocresol green and the intensity of the colour obtained photometrically (Dialab Produktion, Austria) as described by Johnson et al., (1999). The normal reference range for albumin concentration was (3.5 $5.2 \mathrm{~g} / \mathrm{dL})$.

\subsubsection{Determination of Haemoglobin Variants and Glycated Haemoglobin}

Haemoglobin parameters $(\mathrm{HbA} 2, \mathrm{HbA}, \mathrm{HbC}$ and $\mathrm{HbS}$ ) were determined by high performance liquid chromatography method using Biorad Variant II (Bio-Rad Laboratories Inc., Hercules, CA, USA). The reference value for $\mathrm{HbA} 2$ variant was normal (2.0 -3.3\%), Beta thalassemia Trait (BTT) $(\geq 3.5 \%)$ (Buch et al., 2016). Normal adult percentage of Haemoglobin was $\mathrm{HbA}(\geq 98 \%), \mathrm{HbF}(<1 \%), \mathrm{HbS}$ $(0 \%), \quad \mathrm{HbC}(0 \%)$; HbAS, Sickle Cell Trait percentage of normal form of $\mathrm{Hb} \mathrm{A}$ was about $60 \%$ with a moderate amount of $\mathrm{HbS}$ (about $40 \%$ ); $\mathrm{HbAC}$, haemoglobin $\mathrm{C}$ trait percentage of normal form of $\mathrm{HbA}$ was about $60 \%$ and moderate amount of $\mathrm{HbC}$ (about 40\%); $\mathrm{HbCC}$, hemoglobin $\mathrm{C}$ disease percentage of $\mathrm{HbC}$ was $80 \%$ and above); $\mathrm{HbSC}$ sickle-haemoglobin C disease percentage was $50 \%$ of $\mathrm{HbC}$ and $50 \%$ of $\mathrm{HbS}$; HbSS Sickle Cell Disease percentage of $\mathrm{HbS}$ was $80 \%$ and above (AACC, 2019). Participants were classified according to WHO criteria: Reference value for $\mathrm{HbAlC}$ was normal $(4-5.6 \%)$ and Prediabetes $(5.7-6.4 \%)$ for the control group and Diabetes $\geq 6.5 \%$ for T2DM group (WHO, 2016).

\subsubsection{Estimation of Serum Parathyroid Hormone (PTH) Level}

Serum PTH was estimated by quantitative enzyme immunoassay technique (Double-antibody sandwich) technique (Melsin Medical, Changchun, PTH, ELISA KIT CAT.NO: EKHU-1533). The reference range for PTH was between 11.0 and 70.6 $\mathrm{pg} / \mathrm{mL}$ (Souberbielle et al 2016). Normal parathyroid status is defined when PTH levels fall within the normal range with normal calcium and phosphate. Hypoparathyroidism was defined by decreased serum calcium and increased phosphorous levels with reduced PTH (Ali Bazi, et al., 2018) while hyperparathyroidism by inappropriately high PTH level with increased calcium and low phosphate (Dariusz et al., 2012).

\subsection{Statistical Analyses}

Analysis of data was done using Statistical Package for Social Sciences (SPSS) version 21.0. Quantitative variables were presented as mean \pm standard error of mean (SEM). Categorical variables were presented as absolute (n) and relative frequencies (in percentage). Comparison of means between two groups and among subdivided groups was done by statistical independent t-test while test of association was determined using Pearson's Chi square test and Analysis of Variance (ANOVA). Post hoc was used to compare difference between the groups. Statistical significance was defined by $\mathrm{p}$ value $<0.05$.

\subsection{RESULTS}

Table 1 shows the parathyroid function of the study participants. $(\mathrm{p}<0.001)$. Among the T2DM and controls, 93 (93\%) vs $96(92.3 \%)$ were found to be normoparathyroid, $3(3 \%)$ vs $1(0.96 \%)$ were hyperparathyroid and $4(4 \%)$ vs $7(6.73 \%)$ were hypoparathyroid respectively. A high percentage of T2DM and healthy controls had normal parathyroid function and minority of the type 2 diabetics and controls had hyperparathyrodism and hypoparathyroidism. There was no significant difference in the parathyroid function among T2DM and controls ( $p>0.005)$. 
Table 1 Parathyroid function among Type 2 Diabetes Mellitus and Control Group

\begin{tabular}{|c|c|c|c|c|c|}
\hline $\begin{array}{l}\text { PARATHYROID } \\
\text { FUNCTION }\end{array}$ & $\begin{array}{l}\text { T2DM } \\
\mathrm{n}=100\end{array}$ & $\begin{array}{c}\text { CONTROL } \\
\mathbf{n}=104\end{array}$ & $\begin{array}{c}\text { TOTAL } \\
\mathbf{N}=\mathbf{2 0 4}\end{array}$ & $\mathrm{X} 2$ & $\mathbf{p}$ \\
\hline Normoparathyroidism & $93(93.0)$ & $96(92.3)$ & $189(92.6)$ & 1.788 & 0.429 \\
\hline Hyperparathyroidism & $3(3.0)$ & $1(0.96)$ & $4(1.96)$ & & \\
\hline Hypoparathyroidism & $4(4.0)$ & $7(6.73)$ & $11(5.4)$ & & \\
\hline Total & $\begin{array}{l}100 \\
(100.0)\end{array}$ & $\begin{array}{l}104 \\
(100.0)\end{array}$ & $204(100.0)$ & & \\
\hline
\end{tabular}

Values are presented in number $(\mathrm{n})$ and $(\%)=$ percentage in parentheses, $\mathrm{N}=$ total number, $\mathrm{X} 2=$ Chisquared test, $\mathrm{p}=$ probability, $*=$ significant at $\mathrm{p} 0.05, \mathrm{~T} 2 \mathrm{DM}=$ Type 2 Diabetes Mellitus participants, Controls $=$ Apparently healthy participants without Type 2 Diabetes Mellitus, 
The prevalence and association of parathyroid function status among T2DM and controls with normal and abnormal genotypes are shown in table 2 . The prevalence of parathyroid function status among the T2DM was (AA and Non AA were 62 $(62 \%)$ and $31(31 \%)$ normoparathyroidism, $2(2 \%)$ and $2(2 \%)$ hypopaathyroidism, 3 $(3 \%)$ and $0(0 \%)$ hyperthyroidism respectively) while the prevalence among the controls were $76(73.1 \%)$ and $20(19.2 \%)$ normoparathyroid, $7(6.73 \%)$ and $0(0 \%)$ hyperparathyroid and $1(0.96 \%)$ and $0(0 \%)$ hypoparathyroid in AA and Non AA respectively. The associations between parathyroid function in T2DM and controls with normal and abnormal haemoglobin genotypes were not significantly different $(\mathrm{p}>0.05)$.

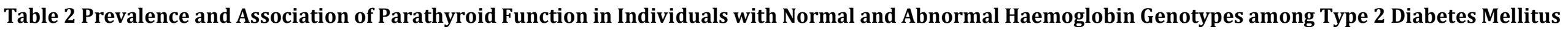
and Control Group.

\begin{tabular}{|c|c|c|c|c|c|c|c|c|c|c|}
\hline \multirow[b]{2}{*}{ Parathyroid Function } & \multicolumn{5}{|c|}{ T2DM $(n=100)$} & \multicolumn{3}{|c|}{ Control $(n=104)$} & \multirow[b]{2}{*}{$\mathrm{X} 2$} & \multirow[b]{2}{*}{$\mathbf{p}$} \\
\hline & AA & Non AA & Total & $\mathrm{X} 2$ & $\mathbf{P}$ & AA & Non AA & Total & & \\
\hline Normoparathyroidism & $(62.0)$ & $31(31.0)$ & $93(93.0)$ & 2.005 & 0.367 & $76(73.1)$ & $20(19.2)$ & $96(92.3)$ & 2.063 & 0.356 \\
\hline Hypoparathyroidism & $2(2.0)$ & $2(2.0)$ & $4(4.0)$ & & & $7(6.73)$ & $0(0.0)$ & $7(6.73)$ & & \\
\hline Hyperparathyroidism & $3(3.0)$ & $0(0.0)$ & $3(3.0)$ & & & $1(0.96)$ & $0(0.0)$ & $1(0.96)$ & & \\
\hline Total & 67 (67) & $33(33.0)$ & $100(100.0)$ & & & $84(80.8)$ & $20(19.2)$ & $\begin{array}{l}104 \\
(100.0)\end{array}$ & & \\
\hline
\end{tabular}

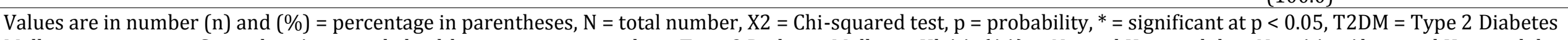

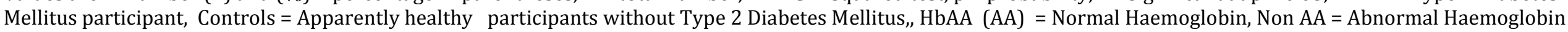




\section{EPRA International Journal of Multidisciplinary Research (IJMR) - Peer Reviewed Journal}

Volume: 7 | Issue: 2 | February 2021|| Journal DOI: 10.36713/epra2013 || SJIF Impact Factor 2021:7.147 || ISI Value: 1.188

Table 3 shows the prevalence and parathyroid function status among T2DM and controls with and without Beta Thalassemia Trait. The prevalence of parathyroid function status among the T2DM was (BTT and NBTT were $5(5 \%)$ and $88(88 \%)$ normoparathyroidism, $0(0 \%)$ and $4(4 \%)$ hypopaathyroidism, $0(0 \%)$ and $3(3 \%)$ hyperthyroidism respectively) while the prevalence among the controls were 6 $(5.8 \%)$ and $90(86.5 \%)$ normoparathyroid, $0(0 \%)$ and $7(6.73 \%)$ hypoparathyroid and $1(0.96 \%)$ and $0(0 \%)$ hyperparathyroid in BTTand NBTT respectively. The association between parathyroid function in T2DM with and without Beta Thalassamia Trait was not significantly different $(\mathrm{p}>0.05)$ but the difference between parathyroid function status in the control group with and without Beta Thalassaemia Trait was significant $(\mathrm{p}<0.05)$

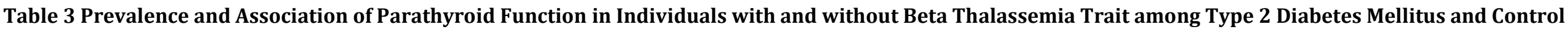

\begin{tabular}{|c|c|c|c|c|c|c|c|c|c|c|}
\hline \multicolumn{11}{|c|}{ Group } \\
\hline \multicolumn{3}{|c|}{ T2DM (n = 100) } & \multicolumn{8}{|c|}{ Control $(n=104)$} \\
\hline Parathyroid Function & BTT & NBTT & Total & $\mathrm{X} 2$ & $\mathbf{P}$ & BTT & NBTT & Total & $\mathrm{X} 2$ & $\mathbf{p}$ \\
\hline Normoparathyroidism & $5(5.0)$ & $88(88.0)$ & $93(93.0)$ & 0.396 & 0.820 & $6(5.8)$ & $90(86.5)$ & $96(92.3)$ & 14.40 & $0.001^{*}$ \\
\hline Hypoparathyroidism & $0(0.0)$ & $4(4.0)$ & $4(4.0)$ & & & $0(0.0)$ & $7(6.73)$ & $7(6.73)$ & & \\
\hline Hyperparathyroidism & $0(0.0)$ & $3(3.0)$ & $3(3.0)$ & & & $1(0.96)$ & $0(0.0)$ & $1(0.96)$ & & \\
\hline Total & $5(5.0)$ & $95(95.0)$ & $100(100.0)$ & & & $7(80.8)$ & $\begin{array}{l}97 \\
(19.2)\end{array}$ & $\begin{array}{l}104 \\
(100.0)\end{array}$ & & \\
\hline
\end{tabular}

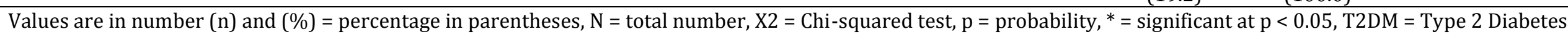
Mellitus participants, Controls = Apparently healthy participants without Type 2 Diabetes Mellitus, BTT = Beta Thalassaemia Trait, NBTT = Individuals without BTT. 


\section{ISSN (Online): 2455-3662}

\section{EPRA International Journal of Multidisciplinary Research (IJMR) - Peer Reviewed Journal}

Volume: 7 | Issue: 2 | February 2021|| Journal DOI: 10.36713/epra2013 || SJIF Impact Factor 2021:7.147 || ISI Value: 1.188

The association of parathyroid function status among T2DM and controls with various haemoglobin genotypes is shown in table 4.The prevalence of parathyroid function status among the T2DM with haemoglobin genotype AA, AC, AS and CC were $62(62 \%), 4(4 \%), 26(26 \%)$ and 1(1\%) normoparathyroid, $\{2(2 \%), 1(1 \%), 1$ $(1 \%)$ and $0(0 \%)\}$ hypopaathyroid respectively and only AA (3\%) had hyperparathyroidism respectively) while the prevalence among the controls with haemoglobin genotype AA, AC, AS and SC were $\{76(73.1 \%), 5(4.81 \%), 14$ $(13.5 \%)$ and $1(0.96 \%)$ \}normoparathyroid. $1(0.96 \%)$ and $7(6.73 \%)$ with AA only were hyperparathyroid and hypoparathyroid in controls respectively. There was no significant difference between the function of the parathyroid gland with different haemoglobin genotypes in both T2DM and controls ( $p>0.05)$

Table 4.0 Prevalence and Association of Parathyroid Function in Individuals with various Haemoglobin Genotypes in Type 2 Diabetes Mellitus and Control Group

\begin{tabular}{|c|c|c|c|c|c|c|c|c|c|c|c|c|}
\hline \multirow[b]{2}{*}{ Parathyroid Function } & \multicolumn{4}{|c|}{ T2DM $(n=100)$} & \multicolumn{8}{|c|}{ Control $(n=104)$} \\
\hline & $\begin{array}{l}\text { HbAA } \\
\text { n (\%) }\end{array}$ & $\begin{array}{l}\text { HbAC } \\
\text { n (\%) }\end{array}$ & $\begin{array}{l}\text { HbAS } \\
\text { n (\%) }\end{array}$ & $\begin{array}{l}\text { HbCC } \\
\text { n (\%) }\end{array}$ & $\begin{array}{l}\text { Total } \\
\text { N (\%) }\end{array}$ & $\mathrm{X} 2(\mathrm{P})$ & $\begin{array}{l}\text { HbAA } \\
\text { n (\%) }\end{array}$ & $\begin{array}{l}\text { HbAC } \\
\text { n (\%) }\end{array}$ & $\begin{array}{l}\text { HbAS } \\
\text { n (\%) }\end{array}$ & $\begin{array}{l}\text { HbSC } \\
\text { n (\%) }\end{array}$ & $\begin{array}{l}\text { Total } \\
\text { N (\%) }\end{array}$ & $\mathrm{X} 2(\mathrm{P})$ \\
\hline Normoparathroidism & $62(62.0)$ & $4(4.0)$ & $\begin{array}{l}26 \\
(26.0)\end{array}$ & $1(1.0)$ & $93(93.0)$ & $\begin{array}{l}5.025 \\
(0.366 \\
)\end{array}$ & $\begin{array}{l}76 \\
(73.1)\end{array}$ & $5(4.81)$ & $\begin{array}{l}14 \\
(13.5)\end{array}$ & $\begin{array}{l}1 \\
(0.96)\end{array}$ & $\begin{array}{l}96 \\
(92.3)\end{array}$ & $\begin{array}{l}2.063 \\
(0.594)\end{array}$ \\
\hline Hyperpararoidism & $3(3.0)$ & $0(0.0)$ & $0(0.0)$ & $0(0.0)$ & $3(3.0)$ & & $1(0.96)$ & $0(0.0)$ & $0(0.0)$ & $0(0.0)$ & $1(0.96)$ & \\
\hline Hypoparathyroidism & $2(2.0)$ & $1(1.0)$ & $1(1.0)$ & $0(0.0)$ & $4(4.0)$ & & $7(6.73)$ & $0(0.0)$ & $0(0.0)$ & $0(0.0)$ & $7(6.73)$ & \\
\hline Total & $67(67)$ & $5(5.0)$ & $27(27)$ & $1(1.0)$ & $100(100.0)$ & & $\begin{array}{l}84 \\
(80.8)\end{array}$ & $5(4.81)$ & $14(13.5)$ & $\begin{array}{l}1 \\
(0.96)\end{array}$ & $\begin{array}{l}104 \\
(100)\end{array}$ & \\
\hline
\end{tabular}

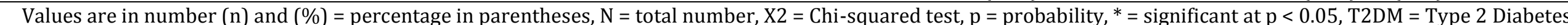

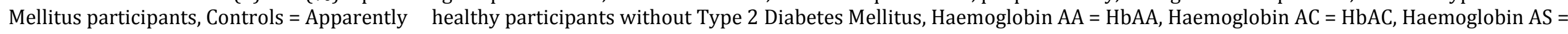
HbAS, Haemoglobin CC = HbCC and Haemoglobin SC = HbSC 
Table 5 shows serum levels of calcium, phosphate, albumin and PTH in T2DM and controls. As shown in table 4 , significant increase in phosphate $(\mathrm{p}<0.001)$ and decrease in albumin concentrations were observed $(\mathrm{p}<0.001)$ in T2DM when compared with controls respectively. Moreover, Calcium was lower while PTH was higher when compared with the controls but the difference were not significant $(\mathrm{P}>0.05)$.

Table 5 Comparison of means values of biochemical parameters between Type 2 Diabetes Mellitus and Control

\begin{tabular}{lcccc}
\hline \multicolumn{5}{c}{ Group } \\
\hline Parameters & Mean (SEM) & Mean (SEM) & t value & p value \\
\hline $\begin{array}{l}\text { Calcium } \\
\text { (mg/dL) }\end{array}$ & $9.03(0.17)$ & $9.12(0.66)$ & -0.123 & 0.902 \\
$\begin{array}{l}\text { Phosphate } \\
\text { (mg/dL) }\end{array}$ & $4.39(0.14)$ & $3.81(0.09)$ & 3.49 & $<0.001^{*}$ \\
$\begin{array}{l}\text { Albumin } \\
\text { (g/dL) }\end{array}$ & & & $<0.001^{*}$ \\
& $4.38(0.43)$ & $4.73(0.07)$ & -4.224 & \\
$\begin{array}{l}\text { PTH } \\
\text { (pg/mL) }\end{array}$ & $31.61(1.93)$ & & & 0.294
\end{tabular}

Values are in mean with SEM = Standard Error of Mean (SEM) in parentheses, $\mathrm{N}=$ total number SEM = Standard Error of Mean, $\mathrm{N}=$ total number, $\mathrm{t}=\mathrm{t}$ tests, $\mathrm{p}=$ probability, ${ }^{*}=$ significant $\mathrm{at} \mathrm{p}<0.05, \mathrm{~T} 2 \mathrm{DM}=\mathrm{Type}$ 2 Diabetes Mellitus participants, Controls = Apparently healthy participants without Type 2 Diabetes, Parathyroid Hormone $=$ PTH

Correlation of PTH with calcium, phosphate and Albumin in T2DM and controls is shown in table 6. There was a negative correlation of PTH with Calcium and albumin in both groups and controls respectively, phosphate was positively correlated in T2DM and controls but no association was found between PTH and all the biochemical parameters $(\mathrm{p}>0.05)$.

Table 6 Correlation of PTH with Calcium, Phosphate and Albumin in Type 2 Diabetes and Controls

\begin{tabular}{|c|c|c|c|c|}
\hline \multirow[b]{3}{*}{ Parameters } & \multirow{3}{*}{$\begin{array}{c}\text { T2DM } \\
\text { PTH (pg/mL) } \\
\text { Pearson Coefficient (r) }\end{array}$} & \multicolumn{2}{|r|}{ CONTROLS } & \multirow[b]{3}{*}{$\mathbf{P}$} \\
\hline & & & $\mathrm{H}(\mathrm{pg} / \mathrm{mL})$ & \\
\hline & & $\mathbf{P}$ & Pearson Coefficient (r) & \\
\hline $\begin{array}{l}\text { Calcium } \\
(\mathrm{mg} / \mathrm{dL})\end{array}$ & -0.092 & 0.364 & -0.104 & 0.292 \\
\hline $\begin{array}{l}\text { Phosphate } \\
\text { (mg/dL) }\end{array}$ & 0.122 & 0.225 & 0.077 & 0.437 \\
\hline $\begin{array}{l}\text { Albumin } \\
(\mathrm{g} / \mathrm{dL})\end{array}$ & 0.119 & 0.237 & -0.105 & 0.289 \\
\hline
\end{tabular}

Parathyroid Hormone $=$ PTH, $\mathrm{p}=$ probability, ${ }^{*}=$ significant at $\mathrm{p}<0.05$ T2DM $=$ Type 2 Diabetes Mellitus participants, Controls $=$ Apparently healthy participants without Type 2 Diabetes 


\section{ISSN (Online): 2455-3662}

\section{EPRA International Journal of Multidisciplinary Research (IJMR) - Peer Reviewed Journal}

Volume: 7 | Issue: 2 | February 2021|| Journal DOI: 10.36713/epra2013 || SJIF Impact Factor 2021:7.147 || ISI Value: 1.188

Table 7 shows the comparison of serum calcium, phosphate, albumin and PTH levels with normal and abnormal haemoglobin genotype in T2DM and controls. ANOVA compared the variables among the normal and abnormal haemoglobin genotypes. There were significant differences in all the biochemical parameters except calcium in T2DM when compared with the control group. Calcium was significantly lower in the T2DM with AA haemoglobin genotype when compared with NON AA of controls $(\mathrm{p}<0.05)$. The mean phosphate concentration of T2DM with AA and Non AA were significantly higher than AA of controls $(p<0.05)$. Serum albumin was significantly lower in T2DM with AA and Non AA compared with the corresponding values of controls with AA and NON AA. The mean concentration of PTH in Type 2 diabetics with AA genotype was significantly higher as compared with NON AA in control individuals $(\mathrm{P}<0.05)$

Table 7 Comparison of Serum Calcium, Phosphate, Albumin and Parathyroid Hormone in Type 2 Diabetes Mellitus and Controls with Normal and Abnormal

\begin{tabular}{|c|c|c|c|c|c|c|c|c|c|}
\hline & \multicolumn{9}{|c|}{$\begin{array}{r}\text { Haemoglobin Genotype } \\
\end{array}$} \\
\hline & \multirow{2}{*}{\multicolumn{2}{|c|}{ T2DM $(n=100)$}} & \multicolumn{3}{|c|}{ CONTROLS $(n=104)$} & & & \multirow[b]{3}{*}{ P3 } & \multirow[b]{3}{*}{ P4 } \\
\hline & & & & (M) $\quad t$ & ANOVA Test & \multicolumn{2}{|c|}{ Post Hoc Analysis } & & \\
\hline PARAMETERS & AA & NON AA & AA & NON AA & $\mathbf{P}$ & P1 & P2 & & \\
\hline $\begin{array}{l}\text { Calcium } \\
\text { (mg/dL) }\end{array}$ & $\begin{array}{l}9.029 \\
(0.196)\end{array}$ & $\begin{array}{l}9.035 \\
(0.344)\end{array}$ & $\begin{array}{l}8.54 \\
(0.19)\end{array}$ & $\begin{array}{l}11.52 \\
(3.38)\end{array}$ & 0.121 & 0.548 & $0.049^{*}$ & 0.628 & 0.077 \\
\hline $\begin{array}{l}\text { Phosphate } \\
\text { (mg/dL) }\end{array}$ & $\begin{array}{l}4.36 \\
(0.172)\end{array}$ & $\begin{array}{l}4.45 \\
(0.23)\end{array}$ & $\begin{array}{l}3.82 \\
(0.10)\end{array}$ & $\begin{array}{l}3.80 \\
(0.23)\end{array}$ & $0.007 *$ & $0.005^{*}$ & 0.062 & $0.009^{*}$ & 0.051 \\
\hline $\begin{array}{l}\text { Albumin } \\
\text { (g/dL) }\end{array}$ & $\begin{array}{l}4.37 \\
(0.06)\end{array}$ & $\begin{array}{l}4.39 \\
(0.06)\end{array}$ & $\begin{array}{l}4.73 \\
(0.09)\end{array}$ & $\begin{array}{l}4.74 \\
(0.12)\end{array}$ & $0.001^{*}$ & $<0.001^{*}$ & $0.017^{*}$ & $0.006^{*}$ & 0.039 \\
\hline $\begin{array}{l}\text { PTH } \\
(\mathrm{pg} / \mathrm{mL})\end{array}$ & $\begin{array}{l}34.57 \\
(2.62)\end{array}$ & $\begin{array}{l}25.59 \\
(2.07)\end{array}$ & $\begin{array}{l}30.97 \\
(2.12)\end{array}$ & $\begin{array}{l}19.76 \\
(2.43)\end{array}$ & $0.008^{*}$ & 0.237 & $0.002^{*}$ & 0.159 & 0.268 \\
\hline
\end{tabular}

Values are in mean with SEM $=$ Standard Error of Mean (SEM) in parentheses, $\mathrm{N}=$ total number SEM $=$ Standard Error of Mean, $\mathrm{N}=$ total number, $\mathrm{p}=$ probability, ${ }^{*}=$ significant at $\mathrm{p}<0.05, \mathrm{~T} 2 \mathrm{DM}=$ Type 2 Diabetes Mellitus participants, Controls $=$ Apparently healthy participants without Type 2 Diabetes, Parathyroid Hormone $=$ PTH, $\mathrm{P}=$ values obtained from ANOVA, P1 = Comparison between AA of T2DM and AA of Controls, P2 = Comparison between AA of T2DM and NON AA of controls, P3 = Comparison between NON AA of T2DM AND AA of Controls, P4 = Comparison between NON AA of T2DM and NON AA of Controls. 
Table 8 shows the comparison of serum calcium, phosphateontrols. The mean phosphate and albumin concentrations of albumin and PTH levels with and without BTT. There weife2DM without BTT were significantly higher and lower significant differences in phosphate and albumin whitlean controls without BTT respectively $(\mathrm{p}<0.05)$.

calcium and PTH were comparable when compared with the

Table 8 Comparison of Serum PTH, Total Calcium, Phosphate and Albumin in Individuals with Type Diabetes Mellitus and Controls with and without BTT

\begin{tabular}{|c|c|c|c|c|c|c|c|c|c|}
\hline \multirow[b]{3}{*}{ PARAMETERS } & \multicolumn{3}{|c|}{ T2DM $(n=100)$} & \multicolumn{6}{|c|}{ CONTROLS $(\mathrm{n}=104)$} \\
\hline & Mea & EM) & & Mean & M) & ANOVA Test & & Post $\mathrm{H}$ & Analysis \\
\hline & BTT & NBTT & BTT & NBTT & $\mathbf{P}$ & P1 & $\mathbf{P 2}$ & P3 & P4 \\
\hline $\begin{array}{l}\text { Calcium } \\
\text { (mg/dL) }\end{array}$ & $\begin{array}{l}8.42 \\
(0.97)\end{array}$ & $\begin{array}{l}9.06 \\
(0.18)\end{array}$ & $\begin{array}{l}9.23 \\
(0.66)\end{array}$ & $\begin{array}{l}9.11 \\
(0.71)\end{array}$ & 0.992 & 0.782 & 0.764 & 0.933 & 0.952 \\
\hline $\begin{array}{l}\text { Phosphate } \\
\text { (mg/dL) }\end{array}$ & $\begin{array}{l}4.65 \\
(0.39)\end{array}$ & $\begin{array}{l}4.38 \\
(0.14)\end{array}$ & $\begin{array}{l}4.26 \\
(0.49)\end{array}$ & $\begin{array}{l}3.78 \\
(0.09)\end{array}$ & $<0.004 *$ & 0.570 & 0.107 & 0.803 & $0.001^{*}$ \\
\hline $\begin{array}{l}\text { Albumin } \\
\text { (g/dL) }\end{array}$ & $\begin{array}{l}4.49 \\
(0.17)\end{array}$ & $\begin{array}{l}4.37 \\
(0.44)\end{array}$ & $\begin{array}{l}4.54 \\
(0.19)\end{array}$ & $\begin{array}{l}4.75 \\
(0 . .76)\end{array}$ & $<0.001 *$ & 0.888 & 0.357 & 0.472 & $<0.001^{*}$ \\
\hline $\begin{array}{l}\text { PTH } \\
\text { (pg/mL) }\end{array}$ & $\begin{array}{l}26.47 \\
(5.62)\end{array}$ & $\begin{array}{l}31.88 \\
(2.01)\end{array}$ & $\begin{array}{l}33.48 \\
(13.07)\end{array}$ & $\begin{array}{l}28.48 \\
(1.75)\end{array}$ & 0.586 & 0.53 & 0.818 & 0.830 & 0.216 \\
\hline
\end{tabular}

Values are in mean with SEM $=$ Standard Error of Mean (SEM) in parentheses, $\mathrm{N}=$ total significant at $\mathrm{p}<0.05$, T2DM $=$ Type 2 Diabetes Mellitus participants, Controls = Apparently healthy participants without Type 2 Diabetes, Parathyroid Hormone $=\mathrm{PTH}, \mathrm{P}=$ values obtained from ANOVA, P1 = Comparison between BTT of T2DM and BTT of Controls, P2 = Comparison between BTT of T2DM and NBTT of controls, P3 = Comparison between NBTT of T2DM AND BTT of Controls, P4 = Comparison between NBTT of T2DM and NBTT of Controls 


\section{ISSN (Online): 2455-3662}

EPRA International Journal of Multidisciplinary Research (IJMR) - Peer Reviewed Journal

Volume: 7 | Issue: 2 | February 2021|| Journal DOI: 10.36713/epra2013 || SJIF Impact Factor 2021:7.147 || ISI Value: 1.188

There were significant differences in phosphate and albumin while calcium and PTH were not statistically significant in T2DM when compared with the control group. Phosphate was significantly higher in T2DM with AA and AC haemoglobin genotype when compared with AA and AC of controls respectively $(p<0.05)$. Serum albumin was significantly lower in T2DM with AA and AC genotypes when compared with the corresponding values of controls with AA and AC respectively. The mean concentration of PTH in Type 2 diabetics with AC genotype was significantly higher $(\mathrm{P}<0.05)$ as compared to $\mathrm{AC}$ in control individuals (Table 9).

Table 9 Comparison of Biochemical Parameters in Individuals with Haemoglobin genotypes in Type 2 Diabetes Mellitus and Control Group

\begin{tabular}{|c|c|c|c|c|c|c|c|c|c|c|c|c|c|c|c|}
\hline & T2DM ( & 100) & Mean (SEM & . & Contro & $n=104)$ & Mean ( & M) ) & & & & & & & \\
\hline $\begin{array}{l}\text { Thyroid } \\
\text { Hormones }\end{array}$ & AA & AC & AS & CC & AA & AC & AS & SC & $\mathbf{t}$ & P1 & P2 & P3 & P4 & P5 & P6 \\
\hline $\begin{array}{l}\text { Calcium } \\
\text { (mg/dL) }\end{array}$ & $\begin{array}{l}9.029 \\
(0.196)\end{array}$ & $\begin{array}{l}8.63 \\
(0.75)\end{array}$ & $\begin{array}{l}9.09 \\
(0.42)\end{array}$ & $\begin{array}{l}9.54 \\
(0.00)\end{array}$ & $\begin{array}{l}8.54 \\
(0.19)\end{array}$ & $\begin{array}{l}8.07 \\
(0.38)\end{array}$ & $\begin{array}{l}13.00 \\
(4.8)\end{array}$ & $\begin{array}{l}7.96 \\
(0.0)\end{array}$ & $\begin{array}{l}1.71 \\
1.28 \\
1.81 \\
0.65 \\
1.08 \\
1.12\end{array}$ & 0.089 & 0.207 & 0.08 & 0.52 & 0.31 & 0.27 \\
\hline $\begin{array}{l}\text { Phosphate } \\
\text { (mg/dL) }\end{array}$ & $\begin{array}{l}4.36 \\
(0.172)\end{array}$ & $\begin{array}{l}4.3 \\
(0.30)\end{array}$ & $\begin{array}{l}4.50 \\
(0.28)\end{array}$ & $\begin{array}{l}3.93 \\
(0.00)\end{array}$ & $\begin{array}{l}3.82 \\
(0.10)\end{array}$ & $\begin{array}{l}3.4 \\
(0.18)\end{array}$ & $\begin{array}{l}3.97 \\
(0.31)\end{array}$ & $\begin{array}{l}3.34 \\
(0.0)\end{array}$ & $\begin{array}{l}2.88 \\
1.50 \\
0.97 \\
0.72 \\
2.54 \\
1.17\end{array}$ & $0.005^{*}$ & 0.140 & 0.34 & 0.48 & $0.04^{*}$ & 0.25 \\
\hline $\begin{array}{l}\text { Albumin } \\
\text { (g/dL) }\end{array}$ & $\begin{array}{l}4.37 \\
(0.06)\end{array}$ & $\begin{array}{l}4.41 \\
(0.14)\end{array}$ & $\begin{array}{l}4.40 \\
(0.06)\end{array}$ & $\begin{array}{l}3.99 \\
(0.00)\end{array}$ & $\begin{array}{l}4.73 \\
(0.09)\end{array}$ & $\begin{array}{l}5.1 \\
(0.17)\end{array}$ & $\begin{array}{l}4.65 \\
(0.14)\end{array}$ & $\begin{array}{l}4.32 \\
(0.0)\end{array}$ & $\begin{array}{l}3.40 \\
3.43 \\
2.02 \\
0.09 \\
3.11 \\
1.87\end{array}$ & $0.001 *$ & $0.001 *$ & 0.047 & 0.93 & $0.015^{*}$ & 0.07 \\
\hline $\begin{array}{l}\text { PTH } \\
(\mathrm{pg} / \mathrm{mL})\end{array}$ & $\begin{array}{l}34.57 \\
(2.62)\end{array}$ & $\begin{array}{l}20.01 \\
(4.94)\end{array}$ & $\begin{array}{l}27.13 \\
(2.27)\end{array}$ & $\begin{array}{l}11.92 \\
(0.00)\end{array}$ & $\begin{array}{l}30.97 \\
(2.12)\end{array}$ & $\begin{array}{l}14.66 \\
(1.36)\end{array}$ & $\begin{array}{l}21.61 \\
(3.34)\end{array}$ & $\begin{array}{l}19.26 \\
(0.0)\end{array}$ & $\begin{array}{l}1.02 \\
2.03 \\
2.13 \\
0.70 \\
1.05 \\
1.39 \\
\end{array}$ & 0.31 & $0.046^{*}$ & 0.036 & 0.49 & 0.33 & 0.17 \\
\hline
\end{tabular}

$\mathrm{p}<0.05$, Haemoglobin AA = HbAA, Haemoglobin AC = HbAC, Haemoglobin AS = HbAS, Haemoglobin CC $=\mathrm{HbCC}$ and Haemoglobin $\mathrm{SC}=\mathrm{HbSC} \mathrm{P} 1=\mathrm{Comparison}$ between $\mathrm{AA}$ of T2DM 
EPRA International Journal of Multidisciplinary Research (IJMR) - Peer Reviewed Journal

Volume: 7 | Issue: 2 | February 2021|| Journal DOI: 10.36713/epra2013 || SJIF Impact Factor 2021:7.147 || ISI Value: 1.188

and AA of Controls , P2 = Comparison between AA of T2DM and AC of controls, P3 = Comparison between AA of T2DM and AS of controls, P4 = Comparison between AA of T2DM and $\mathrm{SC}$ of controls, P5 = Comparison between AC of T2DM and AC of controls and P6 = Comparison between AS of T2DM and AS of controls

Table 10 shows the comparison of PTH, calcium, phosphate and albumin levels according to parathyroid function status in T2DM and controls.

There were significant differences in phosphate and albumin while calcium and PTH were not significantly different in T2DM and controls.

Serum phosphate and albumin were significantly higher and lower in the normoparathyroid group with T2DM and controls respectively ( $<<0.05$ ).

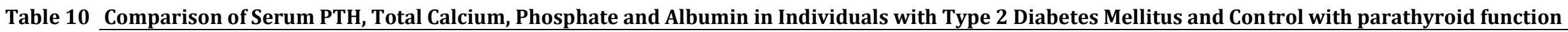
T2DM (n= 100) CONTROL (n= 104)

\begin{tabular}{|c|c|c|c|c|c|c|c|c|c|c|}
\hline & $\begin{array}{l}\text { Mean } \\
\text { (SEM) }\end{array}$ & $\begin{array}{l}\text { Mean } \\
\text { (SEM) }\end{array}$ & $\begin{array}{l}\text { Mean } \\
\text { (SEM) }\end{array}$ & $\begin{array}{l}\text { Mean } \\
\text { (SEM) }\end{array}$ & $\begin{array}{l}\text { Mean } \\
\text { (SEM) }\end{array}$ & $\begin{array}{l}\text { Mean } \\
\text { (SEM) }\end{array}$ & $\begin{array}{l}t \\
\text { value }\end{array}$ & & p value & \\
\hline & NPT & HPT & HPPT & NPT & HPT & HPPT & $\mathbf{t}$ & P1 & P2 & P3 \\
\hline $\begin{array}{l}\text { Calcium } \\
(\mathrm{mg} / \mathrm{dL})\end{array}$ & $\begin{array}{l}9.12 \\
(1.68)\end{array}$ & $\begin{array}{l}8.80 \\
(1.46)\end{array}$ & $\begin{array}{l}6.69 \\
(2.61)\end{array}$ & $\begin{array}{l}9.15 \\
(7.04)\end{array}$ & $\begin{array}{l}8.78 \\
(1.52)\end{array}$ & $\begin{array}{l}8.43 \\
(0.0)\end{array}$ & $\begin{array}{l}-0.041 \\
0.020 \\
-0.576\end{array}$ & 0.968 & 0.985 & 0.623 \\
\hline $\begin{array}{l}\text { Phosphate } \\
\text { (mg/dL) }\end{array}$ & $\begin{array}{l}4.36 \\
(1.34)\end{array}$ & $\begin{array}{l}4.28 \\
(1.29)\end{array}$ & $\begin{array}{l}5.54 \\
(2.66)\end{array}$ & $\begin{array}{l}3.80 \\
(0.88)\end{array}$ & $\begin{array}{l}3.76 \\
(1.21)\end{array}$ & $\begin{array}{l}5.83 \\
(0.0)\end{array}$ & $\begin{array}{l}3.403 \\
0.673 \\
-0.093\end{array}$ & $0.001 *$ & 0.518 & 0.934 \\
\hline $\begin{array}{l}\text { Albumin } \\
\text { (g/dL) }\end{array}$ & $\begin{array}{l}4.37 \\
(0.42)\end{array}$ & $\begin{array}{l}4.37 \\
(0.36)\end{array}$ & $\begin{array}{l}4.54 \\
(0.83)\end{array}$ & $\begin{array}{l}4.75 \\
(0.76)\end{array}$ & $\begin{array}{l}4.60 \\
(3.67)\end{array}$ & $\begin{array}{l}4.33 \\
(0.0)\end{array}$ & $\begin{array}{l}-4.204 \\
-1.028 \\
0.218\end{array}$ & $<0.001^{*}$ & 0.331 & 0.848 \\
\hline $\begin{array}{l}\text { PTH } \\
(\mathrm{pg} / \mathrm{mL})\end{array}$ & $\begin{array}{l}30.22 \\
(14.10)\end{array}$ & $\begin{array}{l}10.28 \\
(0.11)\end{array}$ & $\begin{array}{l}103.13 \\
(23.50)\end{array}$ & $\begin{array}{l}29.30 \\
(16.73)\end{array}$ & $\begin{array}{l}10.44 \\
(0.63)\end{array}$ & $\begin{array}{l}110.99 \\
(0.0)\end{array}$ & $\begin{array}{l}0.408 \\
-0.489 \\
-0.290\end{array}$ & 0.684 & 0.636 & 0.799 \\
\hline
\end{tabular}

Values are in mean with SEM = Standard Error of Mean (SEM) in parentheses, $\mathrm{N}=$ total number $\mathrm{SEM}=\mathrm{Standard}$ Error of Mean, $\mathrm{N}=\mathrm{total}$ number, $\mathrm{t}=\mathrm{t}$ tests, $\mathrm{p}=$ probability, ${ }^{*}=$ significant at $\mathrm{p}<0.05$, Parathyroid Hormone = PTH , NPT = Normoparathyroidism, HPT = Hypoparathyroidism , HPPT = Hyperparathyroidism P1 = Comparison between NPT of T2DM and NTP of Controls, P2 = Comparison between HPT of T2DM and HPT of controls, P3 = Comparison between HPPT of T2DM and HPTT of controls 


\subsection{DISCUSSION}

Elevated levels of Parathyroid Hormone (PTH) has been associated with insulin resistance, beta cell dysfunction, abnormal glucose levels with eventual development of diabetes in recent studies (Kramer et al., 2014). However, increased frequency of functional hypoparathyroidism in patients with type 2 diabetes mellitus with impaired blood sugar regulation have also been reported (Seddek et al., 2016). Parathyroid hormone has some regulating effects on osteoblasts and any discrepancy in its concentration could result in bone loss and increased risk of fracture (Wang et al., 2005 \& Motyl et al., 2012). Bone disease denotes a perceptible cause of mobidity in persons with thalassaemia and other haemoglobin disorders (Voskaridou et al., 2013).

In our study, normal parathyroid function, hyperparathyroidism and hypoparathyroidism were present in $93 \%$ vs $96 \%, 3 \%$ vs $0.96 \%$ and $4 \%$ vs $6.73 \%$ in $\mathrm{T} 2 \mathrm{DM}$ and controls respectively. No significant association of parathyroid function in the T2DM and controls was observed $(p>0.05)$. The parathyroid function status among T2DM and controls with AA and Non AA who had normoparathyroid, hyperparathyroid and hypoparathyroid were $62 \%$ vs $31 \%, 3 \%$ vs $0 \%$ and $2 \%$ vs $2 \%$ respectively $(p>0.05)$. The association between parathyroid function in T2DM and controls with normal and abnormal haemoglobin genotypes was also not significantly different ( $\mathrm{p}>0.05)$. Parathyroid dysfunction was not found in T2DM with BTT while $0.96 \%$ of the control group with BTT had hypoprathyroidism. The association between parathyroid function in T2DM with and without Beta Thalassamia Trait was not significantly different $(p>0.05)$ but the difference between parathyroid function status in the control group with and without Beta Thalassaemia Trait was significant $(p<0.05)$. No significant difference between the function of the parathyroid gland with different haemoglobin genotypes in both T2DM and controls $(p>0.05)$ was observed. Hypoparathyroidism was present in T2DM and controls with Haemoglobin genotype AA (2\%), AC (1\%) and AS (1\%) vs 6.73 in controls respectively while hyperthyroidism was present in T2DM and controls with only Haemoglobin genotype AA (3\%) and (0.96\%) respectively. There was no significant difference between the function of the parathyroid gland with different haemoglobin genotypes in both T2DM and controls $(\mathrm{p}>0.05)$.

The low prevalence of hyperparathyroidism of in our study in the case and control groups is consistent with the study of Taylor et al., (1997) who reported $0.99 \%$ in diabetic patients and increased by three times more when compared with the general population. Taylor in 1991, also observed the frequency of $7.8 \%$ in 205 diabetic patients with primary hyperparathyroidism and 3.0\% among 200 successive patients without hyperparathyroidism attending the same medical clinic. Hyperparathyroidism may possibly be the long-term status of hypercalcaemia and hypophosphatemia which triggers insulin resistance and hyperinsulinemia, and reduces the number of insulin receptors (Kumar et al., 1994). Several other studies also reported low prevalence rate of hypoparathyroidism ranging from 0.5 to $7.6 \%$ in thalassaemic patients (Shamshirsaz et al., 2003; Gamberini et al., 2008 and Canatan, 2013). In this study, we observed low prevalence of hyperparathyroidism $(0.96 \%)$ in controls with BTT. However, hypoparathyroidism was not detected in T2DM and controls with BTT. This parathyroid dysfunction in controls with BTT in this study may likely be due to iron deposition in the parathyroid gland as reported by Habeb et al., (2013) in beta thalassaemic patients.

Recently, Egshatyan (2017) observed magnesium dependent PTH suppression with development of transient hypoparathyroidism and hypocalcemia in T2DM patients. Hypoparathyroidism briefness with associated hypomagnesemia was confirmed after normalization of the blood magnesium level and that vitamin D deficiency may be the possible cause of hypomagnesemia and functional hypoparathyroidism. Similarly, previous studies revealed that T2DM patients with hypomagnesemia, inadequately normal or lowered parathyroid hormone (PTH) that resulted from inhibition of its secretion or synthesis may develop PTH resistance with vitamin D deficiency and hypocalcemia (Hermans et al., 1996; Chase et al., 1974; Rude et al., 1978; Fatemi et al., 1991; Rude et al., 1976; Rude et al., 1985). In our study, the hypoparathyroidism observed in persons with $\mathrm{HbAS}$, HbAC and HbSC in T2DM and HbAA in controls may be due to the lack or excess magnesium playing a role in defective cyclic AMP generation in the parathyroid glands interfering with PTH synthesis and secretion.

Our study revealed a significant increase in phosphate, decrease in albumin and calcium concentrations were observed $(\mathrm{p}<0.05)$ in T2DM compared with controls respectively. Moreover, calcium was lower while PTH was higher in T2DM when compared with the control group but the difference were not significant $(\mathrm{P}>0.05)$. Hussain et al., (2018) reported similar results but the difference in PTH, calcium, and phosphate concentrations between T2DM patients and healthy controls were not significant. In addition, Atmaca et al., (2014) also reported no significant difference in calcium and albumin with statistical difference in phosphorous with PTH below and above $65 \mathrm{ng} / \mathrm{mL}$ in diabetic patients with vitamin D levels $<30 \mathrm{ng} / \mathrm{mL}$. This is in agreement with our findings. Reis et al., (2016) also 
reported higher levels of PTH among blacks compared with whites in diabetes and no significant association was observed this is in line with our study outcome. Serum phosphate and albumin were significantly higher and lower in the normoparathyroid group with T2DM and controls respectively $(\mathrm{p}<0.05)$. Alterations in calcium metabolism in addition to vitamin D deficiency in Diabetic patients, particularly poorly controlled ones may manifest as reported by Atmaca et al., 2014. Deficient PTH secretion, lower calcium and lower serum magnesium are present in poorly controlled diabetics compared to controls, whereas patients with good metabolic control have normal calcium ion and PTH secretion (Paula et al., 2001). The comparable differences observed in our study group may be due to well controlled Type 2 Diabetes Mellitus.

In this present study, there was negative correlation of PTH with Calcium and albumin while phosphate was positively correlated but no significant correlation found between PTH and all the biochemical parameters in the T2DM and controls ( $p>0.05$ ). Arora et al., (2018) observed significant negative correlation of serum calcium and positive correlation of phosphate with PTH. This is in agreement with the observation in our study but the difference not significant.

There were significant differences in all the biochemical parameters except calcium in T2DM when compared with the control group. Calcium and albumin concentrations were significantly lower in T2DM with AA when compared with NON AA and AC of controls $(p<0.05)$. The concentrations of PTH and phosphate were significantly higher in T2DM with $\mathrm{AA}$ and $\mathrm{AC}$ than NON AA and $\mathrm{AC}$ of controls $(p<0.05)$. The control individuals with increased levels of calcium may likely be due to calcium supplementation. Ca intake may lead to an elevation of serum $\mathrm{Ca}$ that activates the $\mathrm{Ca}$-sensing receptor $(\mathrm{CaR})$ in the parathyroid glands to reduce $\mathrm{PTH}$ secretion (Peacock et al., 2010).

The mean phosphate and albumin concentrations of T2DM without BTT were significantly higher and lower than controls without BTT respectively $(\mathrm{p}<0.05)$ while calcium and PTH were comparable with and without BTT $(\mathrm{p}<0.05)$. However, the mean concentration of PTH was higher in Controls with BTT than controls without BTT. Tong et al. (2002) reported that beta thalassemia minor patients with normal glucose tolerance have higher fasting insulin levels and insulin resistance (HOMA-IR) than healthy controls without BTT. Increased PTH level in controls with BTT may be associated with insulin resistance (Kurra et al., 2014).

The difference in phosphate and albumin were significant while calcium and PTH not significantly different in T2DM and controls with parathyroid function. Serum phosphate and albumin were significantly higher and lower in the normoparathyroid group with T2DM and controls respectively $(\mathrm{p}<0.05)$. In this present study, there was negative correlation of PTH with Calcium and albumin while phosphate was positively correlated but no significant correlation found between PTH and all the biochemical parameters in the T2DM and controls ( $p>0.05$ ). Arora et al., (2018) observed significant negative correlation of serum calcium and positive correlation of phosphate with PTH. This is in agreement with the observation in our study but the difference was not significant. It seems that type 2 diabetics and apparently healthy individuals with Haemoglobin genotype AA are more likely to have hypoparathyroidism and hyperparathyroidism. There is also a probability that apparently healthy individuals with BTT may be considered to have hypoparathyroidism.

\subsection{CONCLUSION}

This study has shown a high prevalence of hypoparathyroidism among Type 2 diabetes Mellitus and control individuals. Hypoparathyroidism is often associated with complications and comorbidities like neuropsychiatric conditions, kidney dysfunction, kidney stones, extra skeletal calcifications, cataracts and fracture. These findings support the importance of parathyroid disorder and haemoglobin variants screening to detect and reduce its long-term complications. Further studies are required to elucidate the mechanisms that could explore the impact of haemoglobinopathies on parathyroid function in Type 2 Diabetes Mellitus.

\section{LIMITATION OF STUDY}

The study limitation was, no measurements of plasma Vitamin D and Magnesium are available for all the participants. Thus, the possibility to determine which individuals were at high risk of primary hyperparathyroidism or secondary hyperparathyroidism due to vitamin D deficiency and magnesium dependent PTH suppression could not be revealed.

\section{CONSENT}

Informed consent was administered to all participants after detailed explanation before being recruited into the study.

\section{ETHICAL APPROVAL}

Approval to conduct the study was obtained from the University of Ibadan /University College Hospital, Ibadan ethics committee and study executed in agreement with the Declaration of Helsinki.

\section{ACKNOWLEDGEMENT}

This study was funded partially by the University of Ibadan, Research Foundation (UIRF). 


\section{COMPETING INTERESTS}

Authors have declared no competing interests.

\section{REFERENCES}

1. Dianna J Magliano, Rakibul M Islam, Elizabeth L M Barr, Edward W Gregg, Meda E Pavkov, Jessica L Harding, Maryam Tabesh, Digsu N Koye, Jonathan E Shaw, Trends in incidence of total or type 2 diabetes: systematic review BMJ 2019;366:15003

2. American Diabetes Association. Classification and diagnosis of diabetes: Standards of Medical Care in Diabetesd2019. Diabetes Care 2019;42(Suppl. 1):S13-S28

3. Cipriani $C$, Colangelo L, Santori R, Renella $M$, Mastrantonio M, Minisola S and Pepe J (2020) The InterplayBetween Bone and Glucose Metabolism. Front. Endocrinol. 11:122. doi: 10.3389/fendo.2020.00122

4. Sorva A, Tilvis RS. Low serum ionized to total calcium ratio: association with geriatric diabetes mellitus and with other cardiovascular risk factors? Gerontology 1990;36:212-216

5. Peacock M. Calcium metabolism in health and disease. Clin J Am Soc Nephrol 2010;5 (Suppl. 1):S23-S30

6. Becerra-Tomás $N$, Estruch $R$, Bulló $M$, et al. (2014) Increased serum calcium levels and risk of type 2 diabetes in individuals at high cardiovascular risk. Diabetes Care 37, 30843091. [PubMed:25139884]

7. Rooney MR, Pankow JS, Sibley SD, et al. (2016) Serum calcium and incident type 2 diabetes: the Atherosclerosis Risk in Communities (ARIC) study. Am J Clin Nutr 104, 1023-1029. [PubMed:27510541

8. 8. Sing CW, Cheng VK, Ho DK, et al. (2016) Serum calcium and incident diabetes: an observational study and meta-analysis. Osteoporos Int 27, 1747-1754. [PubMed: 26659066]

9. Mears D. Regulation of insulin secretion in islets of Langerhans by $\mathrm{Ca}(2+)$ channels. J Membr Biol 2004;200: 57-66

10. Zaccardi F, Webb DR, Carter P, et al. (2015) Association between direct measurement of active serum calcium and risk of type 2 diabetes mellitus: a prospective study. Nutr Metab Cardiovasc Dis 25, 562-568. [PubMed: 25933474]

11. 11. Wollheim $C B$ \& Sharp $G W$ (1981) Regulation of insulin release by calcium. Physiol Rev 61, 914-973. [PubMed: 6117094]

12. Begum N, Leitner W, Reusch JE, Sussman KE, Draznin B. GLUT-4 phosphorylation and its intrinsic activity. Mechanism of Ca (2+)-induced inhibition of insulin-stimulated glucose transport. J Biol Chem 1993;268: 3352 3356

13. Ojuka EO, Jones TE, Nolte LA, et al. Regulation of GLUT4 biogenesis in muscle: evidence for involvement of AMPK and $\mathrm{Ca}(2+)$. Am J Physiol Endocrinol Metab 2002;282:E1008-E1013
14. 14.Procopio M, Magro G, Cesario F, et al. The oral glucose tolerance test reveals a high frequency of both impaired glucose tolerance and undiagnosed Type 2 diabetes mellitus inprimary hyperparathyroidism. Diabet Med2002;19:958961

15. Mears D (2004) Regulation of insulin secretion in islets of Langerhans by $\mathrm{Ca}(2+)$ channels. $J$ Membr Biol 200, 57-66.

16. Becerra-Tomás $N$, Estruch $R$, Bulló $M$, et al. (2014) Increased serum calcium levels and risk of type 2 diabetes in individuals at high cardiovascular risk. Diabetes Care 37, 30843091 .

17. Zaccardi F, Webb DR, Carter P, et al. (2015) Association between direct measurement of active serum calcium and risk of type 2 diabetes mellitus: a prospective study. Nutr Metab Cardiovasc Dis 25, 562-568.

18. 18.Seino $Y$ \& Ishida $H$ (1995). Diabetic osteopenia.Pathophysiology and clinical aspects.Diabetes and Metabolism Reviews, 11: 21-35.

19. Chang E, Donkin SS, Teegarden D. Parathyroid hormone suppresses insulin signaling in adipocytes. Mol Cell Endocrinol 2009; 307: 7782.

20. Stanley T, Bredella MA, Pierce L, Misra M. The ratio of parathyroid hormone to vitamin $D$ is a determinant of cardiovascular risk and insulin sensitivity in adolescent girls. Metab Syndr Relat Disord 2013; 11: 56-62.

21. Chiu KC, Chuang LM, Lee NP, et al. Insulin sensitivity is inversely correlated with plasma intact parathyroid hormone level. Metabolism. 2000;49: 1501-5.

22. 22 Reis JP, von Muhlen D, Kritz-Silverstein D, Wingard DL, Barrett-Connor E. Vitamin D, parathyroid hormone levels, and the prevalence of metabolic syndrome in community-dwelling older adults. Diabetes Care. 2007; 30(6):15491555.

23. 23.Reis JP, von Muhlen D, Miller ER 3rd. Relation of 25-hydroxyvitamin $D$ and parathyroid hormone levels with metabolic syndrome among US adults. Eur J Endocrinol. 2008; 159(1):41-48.

24. 24.Kramer $C K$, Swaminathan B, Hanley $A J$, Connelly $P W$, Sermer $M$, Zinman $B$, et al. Prospective associations of vitamin D status with beta-cell function, insulin sensitivity, and glycemia: the impact of parathyroid hormone status. Diabetes. 2014; 63(11):3868-3879.

25. 25.Rahimi Z. Parathyroid hormone, glucose metabolism and diabetes mellitus $J$ Parathyr Dis 2014; 2(1): 55-56.

26. Werner S, Hjern B, Sjoberg HE. Primary hyperparathyroidism. Analysis of findings in a series of 129 patients. Acta Chir Scand. 1974; 140(8):618-625

27. Ljunghall S, Palmer M, Akerstrom G, Wide L. Diabetes mellitus, glucose tolerance and insulin response to glucose in patients with primary hyperparathyroidism before and after 
parathyroidectomy. Eur J Clin Invest. 1983; 13(5):373-377

28. Cheung PS, Thompson NW, Brothers TE, Vinik AI. Effect of hyperparathyroidism on the control of diabetes mellitus. Surgery. 1986; 100(6):1039-1047.

29. Taylor WH. The prevalence of diabetes mellitus in patients with primary hyperparathyroidism and among their relatives. Diabet Med. 1991; 8(7):683-687.

30. Dariusz Sagan, Jerzy S. Tarach, Andrzej Nowakowski, Maria Klatka,Elżbieta CzekajskaChehab, Andrzej Drop,Beata Chrapko and Janusz Klatka Mediastinal Parathyroidectomy: Preoperative Management of Hyperparathyroidism https://www.researchgate.net/publication/221924 900 February 2012] DOI: 10.5772/38188 . Source: InTech

31. Murray TM, et al. Parathyroid hormone secretion and action: Evidence for discrete receptors for the carboxyl-terminal region and related biological actions of carboxyl terminal ligands. Endocr Rev. 2005;26:78-113.

32. Ivarsson KM, Clyne N, Almquist M, Akaberi S.Hyperparathyroidism and new onset diabetes after renal transplantation. Transplant Proc 2014; 46: 145-50.

33. Hamed EA, Abu FaddanNH, Adb Elhafeez HA, Sayed D. Parathormone - 25(OH)-vitamin D axis and bone status in children and adolescents with type 1 diabetes mellitus. Pediatr Diabetes 2011; 12: 536-46.

34. Chern JP, Lin KH. Hypoparathyroidism in transfusiondependent patients with beta thalassemia. J Pediatr Hematol Oncol 2002; 24:291-293

35. Yamamoto $M$, Yamaguchi $T$, Nawata $K$ et al. Decreased PTH levels accompanied by low-bone formation are associated with vertebral fractures in postmenopausal women with type 2 diabetes. $J$ Clin Endocrinol Metab 2012; 97: 1277-1284.

36. Wang YH, Liu Y, Buhl K, Rowe DW. Comparison of the action of transient and continuous PTH on primary osteoblast cultures expressing differentiation stage-specific gfp. J Bone Miner Res. 2005;20(1):5-14.

37. Ali Bazi, Hadi Harati, Ali Khosravi-Bonjar, Elham Rakhshani,4 and Mojtaba Delaramnasab Hypothyroidism and Hypoparathyroidism in Thalassemia Major Patients: A Study in Sistan and Baluchestan Province, Iran Int J Endocrinol Metab. 2018; 16(2):e13228 doi: 10.5812/ijem.13228

38. Dobnig H, Piswanger-Solkner JC, Roth $M$ et al. Type 2 diabetes mellitus in nursing home patients: effects on bone turnover, bone mass, and fracture risk. J Clin Endocrinol Metab 2006; 91: 3355-3363.

39. Yavari. Epidemiology textbook of prevalent diseases in Iran. Nasher Publication Gap 20132014; 9(5): 1151-4.

40. Al-Akhras A, Badr M, El-Safy U, Kohne E, Hassan T, Abdelrahman $H$, et al.Impact of genotype on endocrinal complications in beta- thalassemia patients. Biomedical reports 2016; 4(6): 728-36.

41. Ersi Voskaridou @Copyright E. Voskaridou and E. Terpos, 2013 Licensee PAGEPress, Italy Thalassemia Reports 2013; 3(s1):e20 doi:10.4081/thal.2013.s1.e2

42. Hothersall EJ, Livingstone SJ, Looker HC, Ahmed SF, Cleland S, Leese GP,et al. Contemporary risk of hip fracture in type 1 and type 2 diabetes: a national registry study from Scotland. J Bone Miner Res. (2014) 29:1054-60. doi: 10.1002/jbmr.2118

43. Sellmeyer DE, Civitelli R, Hofbauer LC, Khosla $S$, Lecka-Czernik B, Schwartz AV. Skeletal metabolism, fracture risk, and fracture outcomes in type 1 and.type 2 diabetes. Diabetes. (2016) 65:1757-66. doi: 10.2337/db16-0063

44. Goonasekera HW, Paththinige CS, Dissanayake VHW.Population screening for hemoglobinopathies. Annu Rev Genomics Hum Genet. 2018;19:355-380.

45. Kohne E. Haemoglobinopathies: clinical manifestations, diagnosis, and treatment. Dtsch Arztebl Int. 2011; 108: 532-540.

46. Payandeh $M$, Rahimi $Z$, Zare ME, Kansestani AN, Gohardehi F, Hashemian AH. Theprevalence of anemia and hemoglobinopathies in the hematologic clinics ofthe Kermanshah province, Western iran. International Journal of HematologyOncology and Stem Cell Research. 2014;8 (2):33.

47. Brancaleoni V, Di Pierro E, Motta I, Cappellini $M$. Laboratory diagnosis of thalassemia. Int $J$ Lab Hematol. 2016;38(S1):32-40

48. Lal G Chandrasena, Hemantha Peiris, Senani Williams and Sisira $H$ Siribaddana. Haemoglobin variants in patients with type 2 diabetes mellitus Asian journal of tropical medicine and public health. September 2010: 41: (5).

49. Leung TY, Lao TT. Thalassaemia in pregnancy. Best Practice \& Research Clinical Obstetrics Gynaecol. 2012; 26 (1):37-51.

50. Giusti A, Pinto V, Forni GL, Pilotto A. Management of betathalassemia-associated osteoporosis. Ann $N \quad Y$ Acad Sci. 2016;1368(1):73-81

51. Helmi N, Bashir M, Shireen A, Ahmed IM. Thalassemia review: Features, dental considerations and management.Electronic Physician. 2017;9(3):4003. doi: 10.19082/4003

52. Nickavar A, Qmarsi A, Ansari S, Zarei E. Kidney Function in Patients With Different Variants of Beta-Thalassemia.Iran J Kidney Dis. 2017;11(2):132-137

53. Goyal Meenu, Pankaj Abrol, Harbans Lal Parathyroid and Calcium Status in Patients with Thalassemia Ind J Clin Biochem (Oct-Dec 2010) 25(4):385-38 DOI 10.1007/s12291-010 0071-5

54. World Health Organization. A report on reviewing and updating the current WHO guidelines on diabetes. Definition and diagnosis of diabetes mellitus and intermediate hyperglycaemia. Report of a WHO/IDF, 2006. 
55. World Health Organization. Global report on diabetes: executive summary. World Health Organization; 2016.

56. Barham D, Trinder P. An improved colour reagent for the determination of blood glucose by the oxidase system. Analyst. 1972;97(151):142 145.doi:10.1039/an 9729700142

57. Benedict, S. R., and Theis, R. C., J. Biol. Chem., 1924, lxi, 63. A Colorimetric Method for the Estimation of Blood Calcium. By Joseph H. Roe and Bernard S. Kahn. (From the Department of Chemistry, George Washington University Medical School, Washington.) (Received for publication, December 19, 1925.

58. Thomas L. Clinical Laboratory Diagnostics. 1st ed. Frankfurt: TH Books Verlagsgesellshaft (1998): 241-247.

59. Johnson A. M. Rohif E. M. and Silverman L. M. (1999): Proteins. In Teltz Textbook of clinical chemistry (3rd ed).

60. Variant II Beta thalassemia short program instruction Manual.

61. AACC (Association of Clinical Biochemistry and Laboratory Medcine) Haemoglobinopathy Evaluation, Haemoglobin Evaluation Haemoglobin Electrophoresis, Isoelectric Focusing or by HPLC. This article was last reviewed on 27June 2018. This article was last modified on 12 June 2019

62. Souberbielle JC, Massart C, Brailly-Tabard S, Cormier C, Cavalier E, Delanaye P et al (2016) Serum PTH reference values established by an automated third-generation assay in vitamin $D$ replete subjects with normal renal function: consequences of diagnosing primary hyperparathyroidism and the classification of dialysis patients. Eu J Endocrinol 174:315-323

63. Ali Bazi, Hadi Harati, Ali Khosravi-Bonjar, Elham Rakhshani,4 and Mojtaba Delaramnasab Hypothyroidism and Hypoparathyroidism in Thalassemia Major Patients: A Study in Sistan and Baluchestan Province, Iran Int J Endocrinol Metab. 2018; 16(2):el3228 doi: 10.5812/ijem.13228

64. Dariusz Sagan1, Jerzy S. Tarach, Andrzej Nowakowski, Maria Klatka, ElżbietCzekajskaChehab, Andrzej Drop,Beata Chrapko and Janusz Klatka Mediastinal Parathyroidectomy: Preoperative Management

Hyperparathyroidism

https://www.researchgate.net/publication/221924 900 February 2012 DOI: 10.5772/38188 Source: InTech

65. Kramer $C K$, Swaminathan B, Hanley AJ, Connelly $P W$, Sermer $M$, Zinman $B$, et al. Prospective associations of vitamin D status with beta-cell function, insulin sensitivity, and glycemia: the impact of parathyroid hormone status. Diabetes. 2014; 63(11):3868-3879.

66. Seddek, Mohamed Yehia, Mohamed Shawky Elsayed, Ayman El-Badawy and Mohammed Abd Elaal ElSha3er. Study of Relationship Between Type 2 Diabetes Mellitus And Functional Hypoparathyroidism. 2016 Int. J. Adv. Res. 4(11), 1088-1094
67. Wang YH, Liu Y, Buhl K, Rowe DW. Comparison of the action of transient and continuous PTH on primary osteoblast cultures expressing differentiation stage-specific gfp. J Bone Miner Res. 2005;20 (1):5-14.

68. Motyl KJ, McCauley LK, McCabe LR. Amelioration of type $i$ diabetes-induced osteoporosis by parathyroid hormone is associated with improved osteoblast survival. J Cell Physiol. 2012;227 (4):1326-34.

69. Ersi Voskaridou (OCopyright E. Voskaridou and E. Terpos, 2013 Licensee PAGEPress, Italy Thalassemia Reports 2013; 3(sl):e20 doi:10.4081/thal.2013.s1.e2

70. Taylor WH, Khaleeli AA, Taylor WH, et al. Prevalence of primary hyperparathyroidism in patients with diabetes mellitus. Diabet Med. 1997; 14(5): 386-389, doi: 10.1002/ (SICI)1096-

9136(199705)14:5<386::AIDDIA362>

3.0.CO;2-3, indexed in Pubmed: 9171255.

71. Taylor WH. The prevalence of diabetes mellitus in patients with primary hyperparathyroidism and among their relatives. Diabet Med. 1991; 8(7):683-687.

72. Kumar S, Olukoga AO, Gordon C, et al. aired glucose tolerance and insulin insensitivity in primary hyperparathyroidism. Clin Endocrinol (Oxf). 1994; 40(1): 47-53

73. Shamshirsaz AA, Bekheirnia MR, Kamgar M, PourzahedgilaniN, Bouzari N, Habibzadeh $M$, Hashemi R, Shamshirsaz AA, Aghakhani S, Homayoun H, et al: Metabolic and endocrinologic complications in betathalassemia major: A multicenter study in Tehran. BMC Endocr Disord 3: 4, 2003.

74. Gamberini MR, De Sanctis V, Gilli $G$. Hypogonadism, diabetes mellitus, hypothyroidism, hypoparathyroidism: incidence and prevalence related to iron overload and chelation therapy in patients with thalassaemia major followed from 1980 to 2007 in the Ferrara Centre. Pediatr Endocrinol Rev. 2008; 6(Suppl 1):158-169. [PubMed: 19337172]

75. Canatan D. The Thalassemia Center of Antalya State Hospital: 15 years of experience (1994 to 2008). J Pediatr Hematol Oncol 2013;35:24-27.

76. Habeb AM, Al-Hawsawi ZM, Morsy MM, AlHarbi AM, Osilan AS, Al-Magamsi MS,Zolaly MA. Endocrinopathies in beta-thalassemia major. Prevalence, risk factors, and age at diagnosis in Northwest Saudi Arabia. Saudi Medical Journal. 2013;34(1):67-73

77. Egshatyan LV. Functional hypoparathyroidism secondary to magnesium defi ciency in long-term users of proton pump inhibi tor. Osteoporosis and bone diseases. 2017;20 (3):102-107.

78. Hermans C, Lefebvre C, Devogelaer JP, Lambert M. Hypocalcaemia and chronic alcohol intoxication: Transient hypoparathy roidism secondary to magnesium defi ciency. Clin. Rheumatol. 1996;15 (2):193-196.

79. Chase LR, Slatopolsky E, Krinski T. Secretion and Metabolic Effi cacy of Parathyroid Hormone in Patients with Severe Hypomagnesemia. J. 
Clin. Endocr. Metab. 1974;38 (3):363-371. doi: 10.1210/jcem-38-3-363.

80. Rude RK, Oldham SB, Sharp CF, Singer FR. Parathyroid Hormone Secretion in Magnesium Deficiency. J. Clin. Endocr. Metab. 1978; 47 (4):800-806.

81. Fatemi S, Ryzen E, Flores J, et al. Eff ect of Experimental Human Magnesium Depletion on Parathyroid Hormone Secretion and 1,25Dihydroxyvitamin D Metabolism*. J. Clin. Endocr. Metab. 1991;73(5):1067-1072.

82. Rude RK, Oldham SB, Singer FR. Functional Hypoparathyroidism and Parathyroid Hormone End-Organ Resistance in Human Magnesium Defi ciency. Clin. Endocrinol. (Oxf.). 1976;5(3):209-224.

83. Rude RK, Adams JS, Ryzen E, et al. Low Serum Concentrations of 1,25-Dihydroxyvitamin $D$ in Human Magnesium Defi ciency. J. Clin. Endocr. Metab. 1985;61 (5):933-940. doi: 10.1210/jcem61-5-933

84. Hussain A, Latiwesh O B, Ali A, et al. (November 28, 2018) Parathyroid Gland Response to Vitamin $D$ Deficiency in Type 2 Diabetes Mellitus: An Observational Study. Cureus 10(11): e3656. DOI 10.7759/cureus.3656

85. Atmaca Murat, Ísmail Acar*, Engin Gönültaş*, İsmet Seven*, Rıfkı Üçler, Senar Ebinç*, Murat Alay, Zehra Candan** Type 2 Diabetes Mellitus and Functional Hypoparathyroidism Turk Jem 2014; 18: 116-120

86. Reis JP, von Muhlen D, Kritz-Silverstein D, Wingard DL, Barrett-Connor E. Vitamin D, parathyroid hormone levels, and the prevalence of metabolic syndrome in community-dwelling older adults. Diabetes Care. 2007; 30(6):15491555.

87. Reis et al., (2016) Parathyroid hormone is associated with incident diabetes in white, but not black adults: The Atherosclerosis Risk

Communities (ARIC) Study Diabetes Metab. 2016 June; 42(3): 162-169. doi:10.1016/j.diabet.2015.12.004.

88. Paula FJ, Lanna CM, Shuhama T, Foss MC. Effect of metabolic control on $\backslash$ parathyroid hormone secretion in diabetic patients.Braz, J Med Biol Res 2001;34:1139-1145

89. Arora K, Goyal G, Soin D, Kumar S, Arora H, Garg C. Correlation of parathyroid hormone levels with mineral status in end-stage renal disease patients. Indian $J$ Endocr Metab 2018;22:735-9

90. Peacock $M$ (2010) Calcium metabolism in health and disease. Clin J Am Soc Nephrol 5, S23-S30.

91. Tong Peter $\mathrm{CY}$, Ng Maggie CY, Ho Vhung S, So Wing $Y$, Li JuneKY, Lam Chris WK, Cockram Clive S, Chan Juliana $C N$ : C-reactive protein and Insulin resistance in subject with thalassemia minor and a family history of diabetes. Diabetes Care 2002, 25:1480-1481.

92. Kurra S, Fink DA, Siris ES. Osteoporosisassociated fracture and diabetes. Endocrinol Metab Clin North Am. 2014;43(1):233-43 